\section{ORTHOPTERA (INSECTA) FROM PONG DAM WETLAND, DISTRICT KANGRA, HIMACHAL PRADESH, INDIA}

\author{
M.S. Shishodia ${ }^{1}$,H.S. Mehta ${ }^{2}$,V.K.Mattu ${ }^{3}$ and S.K. Thakur ${ }^{2}$ \\ ${ }^{I}$ Retired Scientist, Zoological Survey of India, Kolkata, West \\ Bengal, India. \\ ${ }^{2}$ High Altitude Zoology Field Station, Zoological Survey of India, \\ Saproon, Solan, Himachal Pradesh, India. \\ ${ }^{3}$ Department of Life sciences, Himachal Pradesh University, \\ Summer Hill, Shimla 171005, India.
}

The number of known species of Orthoptera from the whole world is about 20,000 and out of these 1,750 species (Tandon \& Hazra, 1998) -- nearly 10\% -- are known from India. They are economically important insects, as some species cause considerable damage to crops, vegetables and forest plantations. The well known locusts belong to this group. Majority of the species are tropical and well represented in temperate and are found from sea level to high altitudes in the Himalaya.

Pong Dam Wetland is one of the largest man made wet lands of northern India, across the river Beas situated at the base of Dhauladhar ranges in Kangra District of Himachal Pradesh. The dam was completed in 1976, primarily for power generation, irrigation and control of floods. The length of the reservoir is $41 \mathrm{~km}$ and its maximum width is $19 \mathrm{~km}$. It has a catchment area of $15,660 \mathrm{~km}^{2}$. An area of 423 acres has been designated as Pong Dam Sanctuary. It is located between $31^{\circ} 80^{\prime}$ to $32^{\circ} 07^{\prime} 26^{\prime \prime} \mathrm{N}$ latitude and $75^{\circ} 80^{\prime}$ to $76^{\circ} 25^{\prime} \mathrm{E}$ longitude. Pong Dam was declared a sanctuary in 1983. In the year 1994, the Ministry of Environment and Forests, Government of India, declared it as a wetland of national importance. The Pong reservoir drains several streams and streamlets on its course from Dehra to Guglara. Five major streams like Ava, Mone, Gaj, Baner and Dehar emanate from the Dhauladhar ranges in Kangra Valley.

The catchment area is dominated by dry deciduous scrubs, Himalayan subtropical pine forest, Khair plantations etc. The area holds some important subtropical fauna and flora. The dominant flora of this area includes Acacia, Jamun, Shisham, Mango, Mulberry, Ficus, Kachnar, Amla and Prunus. Apart from these tree species a variety of shrubs, grasses and climbers are found.
Besides, a large area of the wetland is under agriculture where crops like wheat, Brassica are grown. A number of grass species cover the area which support reasonably good orthopteran insects.

There is no consolidated and authentic records available on orthopteran diversity of this wetland area. Keeping this in view a number of surveys were made from January 2000 to December 2001. The present paper depicts altogether, 39 species belonging to 35 genera, under eight families, belonging to super families Acridoidea (Short-horned Grasshoppers), Tetrigoidea (Grouse-Locusts), Tettigonioidea (Long-horned Grasshoppers), and Grylloidea (Crickets).

Orthopteran (Insecta) diversity of Pong Dam Wetland and Catchment area, District Kangra, Himachal Pradesh is listed below.

\section{Systematic list \\ FamilyAcrididae \\ $\underline{\text { Subfamily Acridinae }}$ \\ Acrida exaltata (Walker) \\ Phlaeoba infumata Brunner}

Subfamily Oedipodinae

Heteropternis respondes

Aiolopus thalassinus tamulus (Fabricius)

Trilophidia annulata (Thunberg)

Oedaleus abruptus (Thunberg)

Sphingonotus longipennis Saussure

Gastrimargus a. africanus (Saussure)

Pusana laevis (Uvarov)

Acrotylus humbertianus Saussure

Subfamily Hemiacridinae

Spathosternum p. prasiniferum (Walker)

Subfamily Oxyinae

Oxya h. hyla Serville

Oxya fuscovittata (Marschall)

Subfamily Gomphocerinae

Dnopherula (Aulacobothrus) socius(Bolivar)

Dnopherula (Aulacobothrus) sp.

Subfamily Coptacridinae

Eucoptacra saturata (Walker)

$\underline{\text { Subfamily Cyrtacanthacridinae }}$

Pachyacris vinosa (Walker)

\section{Family Pyrgomorphidae}

Aularches miliaris (Linnaeus)

Atractomorpha crenulata (Fabricius)

Chrotogonus (C.) t. trachypterus (Blanchard)

Poikilocerus pictus (Fabricius)

Pyrgomorphasp. 


\author{
Family Tetrigidae \\ Hedotettix attenuatus Hancock \\ Hedotettix gracilis (DeHann) \\ Ergatettix dorsiferus (Walker)
}

Family Gryllotalpidae

Gryllotalpa africana Beauvois

\section{Family Gryllidae}

Teleogryllus testaceus (Walker)

Teleogryllus occipitalis (Serville)

Plebeiogryllus guttiventris (Walker)

Loxoblemmus detectus (Serville)

Pteronemobius fascipes (Walker)

Gryllus bimacultus De Geer

Modicogryllus confirmatus (Walker)

Family Phalangopsidae

Homoegryllus cincticornis (Walker)

Family Trigonidiidae

Trigonidium cicindeloides Rambur

Family Tettigoniidae

Mecapoda elongata (Linn.)

Ducetia japonica (Thunberg)

Holochlora indica Kirby

Letana megastridula Ingrisch

\section{Acknowledgement}

We are grateful to Dr. J.R.B. Alfred Director, Zoological Survey of India, Kolkata for laboratory facilities; to Dr. R.M. Sharma Scientist C, HAZFS, ZSI Solan for various help and completion of this manuscript; to Sh. K.L. Sharma and staff of the station for their cooperation.

\section{References}

Bhowmick, H.K. and P. Halder (1984). Preliminary distribution with remarks on little known species of Acrididae (Orthoptera: Insecta) from the western Himalayas (Himachal Pradesh). Records of the Zoological Survey of India 18(1\&2): 167-191.

Bhowmick, H.K. (1985). Contribution to the gryllidae fauna of the Western Himalayas (Orthoptera: Gryllidae) Records of the Zoological Survey of India, Occasional Paper No.73, pp.1-74.

Bhowmick, H.K. (1990). Indian species of the genus Aulacobothrus Boliver (Orthoptera: Acrididae). Records of the Zoological Survey of India 86: 413-423.

Chopard, L. (1969). Fauna of India Orthoptera Grylloidae Vol. 2. 421pp. Published by the Zoological Survey of India, Calcutta.

Julka, J.M., S.K. Tandon, P. Halder and M.S. Shishodia (1982). Ecological observation on the grasshoppers (Orthoptera: Acridoidea) din Solan (H.P.), India. Oriental Insects 61: 63-71.

Uvarov, B.P. (1927). Distributional records of Indian Acrididae. Records of the Indian Museum 28: 233-240.

\section{CASSIA FISTULA LINNAEUS: A NEW LARVAL FOOD PLANT OF THE COMMON SAILER BUTTERFLY, NEPTIS HYLAS (MOORE) (LEPIDOPTERA: NYMPHALIDAE)}

\author{
Vinayan. P.Nair \\ 3/IV College Quarters, P.O. Madappally College, Vatakara, Kozhikode \\ District, Kerala 673102, India.
}

During May 2002, while collecting some Common Emigrant (Catopsilia pomona (Fabricius)) larvae from Cassia fistula near the Government College Campus, Madappally, Kozhikode District, Kerala, I saw two Nymphalid eggs on the leaf tips of that plant, one of which I collected and kept for hatching while the other I left on the leaf. Later a brown coloured larva emerged from these eggs, both in the field and in the laboratory. Upon maturity, it emerged as the Common SailerNeptis hylas (Moore) (Lepidoptera: Nymphalidae).

Common Sailer larva reportedly feeds on Cylista sp., Lathyrus sp., Mucuna purpurea, Xylia xylocarpa, Canavalia gladiata,Vigna cylindrica, Vigna unguiculata, Paracalyx scariosa (Fabaceae), Ceiba pentandra, Bombax ceiba (Bombacaceae), Triumfetta rhomboidea, Corchorus capsularis, Corchorus olitorius, Grewia tiliaefolia (Tiliaceae), Nothapodytes nimmoniana (Icacinaceae), Helicteres isora (Sterculiaceae) and Flemingia macrophylla (Acanthaceae) (Wynter-Blyth, 1957; Kunte, 2000).

Cassia fistula (Caesalpiniaceae) was not recorded so far as a food plant of the Common Sailer larva. The occurrence and successful rearing of Common Sailer on Cassia fistula confirms it as a new larval food plant.

\section{Acknowledgements}

I thank Dr. C. Radhakrishnan (Joint Director, ZSI, Western Ghats Field Research Station, Kozhikode), Dr. P.M. Sureshan and Md. Jafer Palot for encouragement and facilities.

\section{References}

Kunte, K.(2000). Butterflies of Peninsular India. Universities Press, Hyderabad.

Wynter-Blyth, M.A. (1957). Butterflies of the Indian Region. Bombay Natural History Society, Bombay. 